\title{
ANALISA PELAKSANAAN PAS FINAL BERDASARKAN PMK No. 165/PMK.03/2017 DAN PP No. 36 Tahun 2017 UNTUK BAHAN AJAR MATA KULIAH PAJAK DAN MANAJEMEM PAJAK
}

\author{
Ahmad Jarnuzi ${ }^{1}$, Hari Purnomo' ${ }^{2}$ Yusna $^{3}$ \\ ${ }_{1,2,3}$ Politeknik Negeri Malang \\ ahmadjarnuzi@polinema.ac.id ${ }^{1}$, haripurnomo@polinema.ac.id ${ }^{2}$, yusnaa@polinema.ac.id ${ }^{3}$
}

(Artikel diterima: Mei 2020, diterima untuk terbit: Juni 2020)

\begin{abstract}
Abstrak - Penelitian ini dilakukan untuk menambah bahan ajar mata kuliah pajak dan praktik pajak. Selain itu penelitian ini berkesinambungan dengan penelitian sebelumnya mengenai pengampunan pajak pada tahun 2016. Pajak berkembang dan berubah sesuai perkembangan perekonomian. Sehingga sebagai pengajar pajak dan praktik pajak harus mengikuti perkembangan dan memahami prosedur pelaksanaan peraturan pajak terbaru, khususnya dalam penelitian ini mengenai Pengungkapan Aset Sukarela Dengan Tarif Final (PAS Final).

Pengungkapan Aset Sukarela Dengan Tarif Final (PAS Final) bertujuan agar wajib pajak yang memiliki harta yang belum dilaporkan dalam SPT PPh sampai dengan tahun 2015 dan tidak diikutkan dalam program pengampunan pajak tidak dikenakan denda Pasal 18 Undang-Undang No. 11 Tahun 2016 tentang Pengampunan Pajak sebesar 200\%. Jika harta yang belum dilaporkan dalam SPT PPh Tahunan sampai dengan tahun 2017 tidak diikutkan program pengampunan pajak maka dianggap sebagai penghasilan yang harus dibayar pokok pajaknya dan denda $200 \%$.
\end{abstract}

Kata kunci: aset, kata, pengampunan pajak, penghasilan.

\section{Pendahuluan}

Program Pengampunan Pajak atau Tax Amnesty telah berakhir tanggal 31 Desember 2017. Menurut Direktorat Jenderal Pajak (DJP), pengampunan pajak telah menghasilkan nilai deklarasi harta sebesar Rp 4.881.000.000.000.000,00 (empat ribu delapan ratus delapan puluh satu trilyun) dengan rincian sebagai berikut : 1 . Deklarasi harta Dalam Negeri Rp 3.697.940.000.000.000,00 (tiga ribu enam ratus sembilan puluh tujuh trilyun sembilan ratus empat puluh milyar rupiah). 2. Deklarasi harta Luar Negeri Rp 1.036.370.000.000.000,00 (seribu tiga puluh enam trilyun tiga ratus tujuh puluh milyar rupiah). 3. Repatriasi sebesar Rp 146.690.000.000.000,00 (seratus empat puluh enam trilyun enam ratus sembilan puluh milyar rupiah) (PJ.091/PPh/S/009/2017/DJP).

Wajib pajak yang berkewajiban menyampaikan Surat Pemberitahuan Tahunan Pajak Penghasilan, baik yang telah mengikuti program Pengampunan Pajak maupun yang tidak mengikuti Pengampunan Pajak dapat mengikuti PAS Final. Bagi wajib pajak yang telah mengikuti pengampunan pajak jika punya harta yang belum dideklarasikan dan belum dilaporkan dalam SPT PPh maka bisa mengikuti program PAS Final. Demikian juga untuk wajib pajak yang belum mengikuti program pengampunan pajak yang belum dilaporkan dalam SPT PPh juga dapat mengikuti program PAS Final.

PAS Final sendiri merupakan suatu singkatan dari Pengungkapan Aset Sukarela Dengan Tarif Final. Dalam PAS Final harta yang tidak diikutkan dalam program pengampunan pajak akan dikenakan pajak sesuai dengan ketentuan PMK No.165/PMK.03/2017 dan dikenakan tarif final yang diatur pada Peraturan Pemerintah PP No.36/2017. Program PAS Final bertujuan agar wajib pajak yang memiliki harta yang belum dilaporkan dalam SPT PPh sampai dengan tahun 2015 dan tidak diikutkan dalam program pengampunan pajak tidak dikenakan denda Pasal 18 Undang-Undang No. 11 Tahun 2016 tentang Pengampunan Pajak sebesar 200\%. Jika diterapkan pasal 18 undang-undang pengampunan pajak maka harta yang belum dilaporkan dalam SPT PPh Tahunan sampai tahun 2015 dan sampai dengan tahun 2017 tidak diikutkan program pengampunan pajak maka dianggap sebagai penghasilan yang harus dibayar pokok pajaknya dan denda 200\% (Pasal 18 UU No. 11 Tahun 2016).

Peneliti melakukan penelitian mengenai PAS Final bertujuan untuk memahami PAS Final sebagai kelanjutan dari penelitian pengampunan pajak yang telah dilakukan tahun 2017 serta untuk membuat bahan ajar mata kuliah pajak dan manajemen pajak dengan judul "Analisa Pelaksanaan PAS Final Berdasarkan PMK No.165/PMK.03/2017 dan PP No.36/2017 untuk Bahan Ajar Mata Kuliah Pajak dan Manajemen Pajak".

\section{TinJaUAn Pustaka}

PMK 165 merupakan perubahan kedua dari Peraturan Menteri Keuangan No.118/KMK.03/2016. PMK 118 merupakan peraturan pelaksanaan undang-undang nomor 11 tahun 2016 tentang pengampunan pajak tahun 2016. Tujuan dikeluarkan PMK 165 adalah untuk lebih memberikan keadilan, pelayanan, kemudahan, dan mendorong kepatuhan Wajib Pajak dalam menjalankan kebijakan Pengampunan Pajak sebagaimana diatur dalam Undang-Undang Nomor 11 Tahun 2016 tentang Pengampunan Pajak atau Tax Amnesti (TA).

Wajib pajak yang telah memperoleh Surat Keterangan dan membayar uang tebusan atas harta tidak bergerak berupa tanah dan/atau bangunan yang belum dibalik nama atas 
nama wajib pajak, harus melakukan pengalihan hak menjadi atas nama wajib pajak. Pengalihan hak atas tanah dan bangunan yang dibebaskan dari pajak penghasilan adalah bagi wajib pajak yang mengajukan permohonan pengalihan hak atau penandatanganan surat pernyataan oleh kedua belah pihak di hadapan notaris yang menyatakan bahwa harta teresebut benar milik wajib pajak yang menyampaikan surat pernyataan, dalam hal harta tersebut belum diajukan permohonan pengalihan hak, keduanya dilakukan dalam jangka waktu paling lambat sampai dengan tanggal 31 Desember 2017 terhadap harta tambahan yang telah diperoleh dan/atau dimiliki Wajib Pajak sebelum akhir tahun pajak. Jika wajib pajak belum melakukan balik nama atas tanah dan/atau bangunan atau saham sampai tanggal 31 Desember 2017 maka atas pengalihan hak yang dilakukan dikenai oajak sesuai dengan ketentuan peraturan perundangundangan yang mengatur mengenai pajak penghasilan. Pembebasan pajak penghasilan atas pengalihan hak dikecualikan apabila telah terjadi pembelian tanah dan atau bangunan oleh wajib pajak dari pengembang dan terhadap hak atas tanah dan atau bangunan dari pengembang yang belum dilakukan balik nama dari pengembang kepada wajib pajak.

Semua Wajib Pajak baik peserta Amnesti Pajak maupun bukan peserta Amnesti Pajak dapat mengungkapkan harta yang belum dilaporkan dalam SPT PPh dan Surat Pernyataan dengan PMK 165 ini. Harta tambahan yang dapat diikutkan dalam pengungkapan harta tambahan setelah masa Amnesti Pajak ini adalah Harta yang belum atau kurang diungkapkan dalam Surat Pernyataan dan Harta yang belum dilaporkan dalam SPT Tahunan sepanjang Direktur Jenderal Pajak belum menemukan data dan/atau informasi mengenai harta dimaksud.

Cara pengungkapan harta tambahan setelah berakhirnya masa Amnesti Pajak adalah dengan menyampaikan SPT Masa PPh Final dilampiri dengan bukti pembayaran $\mathrm{PPh}$ atas harta. Cara menghitung PPh Final yang terutang atas pengungkapan harta tambahan setelah berakhirnya masa Amnesti Pajak adalah Pajak Penghasilan dihitung dengan cara mengalikan tarif sesuai dengan PP 36 Tahun 2017 dengan Dasar Pengenaan Pajak Penghasilan. Tarif yang dipergunakan untuk menghitung PPh Final atas pengungkapan harta tambahan setelah berakhirnya masa Amnesti Pajak adalah WP Badan sebesar 25\%; WP Orang Pribadi sebesar 30\%; dan WP Tertentu sebesar 12,5\%.(PP 36/2017)

Wajib Pajak Tertentu adalah Wajib Pajak yang menerima penghasilan bruto dari usaha dan atau pekerjaan bebas pada Tahun Pajak Terakhir paling banyak sebesar Rp 4,8 miliar; Wajib Pajak yang menerima penghasilan bruto selain dari usaha dan atau pekerjaan bebas pada Tahun Pajak Terakhir paling banyak sebesar Rp 632 juta; dan Wajib Pajak menerima penghasilan gabungan dengan ketentuan jumlah penghasilan bruto yang bersumber selain dari usaha dan/atau pekerjaan bebas paling banyak sebesar Rp632 juta; dan jumlah penghasilan bruto paling banyak sebesar $R p 4,8$ miliar yang bersumber dari usaha dan atau pekerjaan bebas dan selain dari usaha danatau pekerjaan bebas.(PP 36/2017).

Cara menentukan nilai yang dijadikan pedoman untuk menghitung besarnya nilai harta adalah nilai nominal, untuk Harta berupa kas atau setara kas; Nilai yang ditetapkan oleh pemerintah yaitu Nilai Jual Objek Pajak (NJOP), untuk tanah dan/atau bangunan dan Nilai Jual Kendaraan
Bermotor (NJKB), untuk kendaraan bermotor; Nilai yang dipublikasikan oleh PT Aneka Tambang Tbk., untuk emas dan perak; Nilai yang dipublikasikan oleh PT Bursa Efek Indonesia, untuk saham dan warrant yang diperjualbelikan di PT Bursa Efek Indonesia; Nilai yang dipublikasikan oleh PT Penilai Harga Efek Indonesia, untuk obligasi negara Republik Indonesia dan obligasi perusahaan, sesuai kondisi dan keadaan Harta pada akhir Tahun Pajak Terakhir. Apabila tidak terdapat nilai yang dapat dijadikan pedoman, Wajib Pajak dapat menggunakan nilai dari hasil penilaian Kantor Jasa Penilai Publik atau nilai dari hasil penilaian Direktur Jenderal Pajak, apabila Wajib Pajak meminta untuk dilakukan penilaian.(PP 36/2017).

Dalam rangka melaksanakan pembangunan nasional NKRI untuk menyejahterahkan dan memakmurkan seluruh rakyat Indoensia secara merata dan berkeadailan. Maka upaya pemungutan pajak untuk kepentingan pembangunan nasional, Pemerintah telah dan sedang melakukan reformasi perpajakan pada Direktorat Jenderal Pajak dengan tujuan untuk memperbaiki organisasi, proses kerja, pengelolaan data dan informasi dari perbankan, serta sumber daya manusia.

Sedangkan berdasarkan faktor eksternal banyaknya wajib pajak yang melakukan pengindaraan pajak ke luar Indonesia maka dibentuk aturan yang mengharuskan pertukaran infromasi antar Negara atau dengan kata lain tersedianya akses yang luas bagi otoritas perpajakan untuk menerima dan memperoleh informasi keuangan bagi kepentingan perpajakan dalam pembentukan basis data perpajakan yang lebih kuat dan akurat. Sehingga, Presiden telah menetapan Peraturan Pemerintah Pengganti UndangUndang Nomor 1 Tahun 2017 tentang Akses Informasi Keuangan Untuk Kepentingan Perpajakan pada tanggal 8 Mei 2017, guna memberikan kepastian hukum mengenai pemberian akses yang luas bagi otoriats perpajakan dalam menerima dan memperoleh informasi keuangan bagi kepentingan perpajakan dan memenuhi komitmen Indonesia dalam perjanjian internasional terkait dengan pertukaran informasi keuangan secara otomatis.

\section{Metode Penelitian}

Penelitian ini adalah penelitian studi kasus sehingga hanya memerlukan satu obyek penelitian saja dalam mencari data yang akan diolah dan digunakan sebagai model untuk memperoleh hasil penelitian. Secara umum, studi kasus merupakan strategi yang lebih cocok bila pokok pertanyaan suatu penelitian berkenaan dengan how atau why, bila peneliti hanya memiliki sedikit peluang untuk mengontrol peristiwa-peristiwa yang akan diselidiki, dan bilamana fokus penelitiaannya terletak pada fenomena kontemporer (masa kini) di dalam konteks kehidupan nyata (Yin,terjemahan Mudzakir, 2002).

Obyek penelitian ini adalah 2 wajib pajak orang pribadi yang membuat Surat Pernyataan untuk mengikuti Pengampunan Pajak. Penelitian ini akan dilakukan di Malang. Penelitian ini menggunakan data sekunder. Data sekunder yaitu data yang dibuat oleh wajib pajak sebagai obyek penelitian. Metode pengumpulan data adalah pengamatan dan dokumentasi. 


\section{Hasil dan Pembahasan}

PAS Final atau Pengungkapan Aset Sukarela dengan Tarif Final adalah program pemerintah setelah Tax Amnesty yang bertujuan untuk memberikan kesempatan bagi wajib pajak yang belum sempat mengungkapkan harta dalam Surat Pengungkapan Harta (SPH) atau Surat Pemberitahuan (SPT) saat program Amensti Pajak maupun wajib pajak yang belum mengikuti Amnesti Pajak dan belum diperiksa oleh fiskus. Harta tersebut dapat diungkapkan oleh wajib pajak melalui SPT Masa PPh Final. PAS Final tidak terbatas waktu sepanjang Dirjen Pajak belum menemukan data atas harta yang dimaksud. Hal ini merupakan kesempatan terbaik bagi wajib pajak untuk melaporkan PAS Final dan selain itu agar terhindar dari pengenaan sanksi Pasal 18 UU Pengampunan Pajak atas Harta yang belum dilaporkan.

Tarif pajak yang dikenakan pada harta yang belum diungkapkan pada periode PAS Final ditetapkan dalam pasal 3 ayat 2 yaitu untuk wajib pajak badan dikenakan tarif $25 \%$, wajib pajak orang pribadi $30 \%$ dan wajib pajak tertentu $12,5 \%$ yang dimaksud dengan wajib pajak tertentu adalah wajib oajak yang menerima penghasilan bruto dari usaha dan/atau pekerjaan bebas pada Tahun Pajak Terakhri paling banyak empat miliar delapan ratus juta rupiah; wajib pajak yang menerima penghasilan bruto selain dari usaha dan/atau pekerjaan bebas pada Tahun Pajak Terakhir paling banyak enam ratus tiga puluh dua juta rupiah atau wajib pajak yang menerima penghasilan bruto dari usaha dan/atau pekerjaan bebas paling banyak empat miliar delapan ratus juta rupiah. Berdasarkan Peraturan Pemerintah No. 36.

Tahun 2017 Pasal 5 dasar pengenaan pajak penghasilan adalah harta bersih tambahan sesuai yang tercantum dalam surat keterangan, harta bersih yang belum atau kurang diungkapkan dalam surat pernyataan, harta bersih yang belum dilaporkan dalam SPT PPh, harta bersih sebesar selisih lebih antara harta bersih yang dilaporkan dalam SPT PPh Terakhir dengan jumlah yang mencerminkan harta bersih yang telah dilaporkan dalam SPT PPh yang disampaikan sebelum SPT PPh Terakhir dan UU Pengampunan Pajak berlaku; harta bersih yang bersumber dari penghasilan pada tahun pajak terakhir; dan harta bersih yang bersumber dari setoran modal dari pemilik atau pemegang saham pada tahun pajak terakhir, dan/atau harta bersih yang belum atau kurang diungkapkan akibat penyesuian nilai harta bersih per akhir tahun pajak terakhir yang tidak dilunasi uang tebusannya.

Dalam menentukan nilai, jika harta tidak memiliki pedoman nilai atau yang tertera pada daftar harta dan cara menilai di atas maka dapat dilakukan dengan cara menentukan nilai harta menggunakan hasil penilaian Kantor Jasa Penilai Publik dan hasil penilaian Direktorat Jenderal Pajak (atas permintaan Wajib Pajak). Selain menentukan dasar penilaian harta, dibutuhkan dokumen pendukung harta yaitu sebagai berikut :

SPT PPB Tahun Pajak Terakhir, untuk tanah dan/atau bangunan. Dokumen yang memuat Nilai Jual Kendaraan Bermotor (NJKB) untuk kendaraan bermotor. Dokumen yang memuat nilai yang dipublikasikan oleh PT Aneka Tambang Tbk., untuk emas dan perak.
Dokumen yang memuat nilai yang dipublikasikan oleh PT Bursa Efek Indonesia, untuk saham dan warrant yang diperjualbelikan di PT Bursa Efek Indonesia.

Dokumen yang memuat nilai yang dipublikasikan oleh PT Penilai Harga Efek Indonesia, untuk obligasi Negara Republik Indonesia dan perusahaan.

Dokumen berupa lembar hasil penilaian Kantor Jasa Penilai Publik atau Direktur Jenderal Pajak, dalam hal tidak terdapat pedoman dalam penentuan nilai Harta.

Cara utuk membayar pajak PAS Final adalah harus membuat ID Billing atau eBilling Tax Amnesty terlebih dahulu. eBilling adala suatu serangkai kode pembayaran yang terdiri dari Kode Akun Pajak (KAP) 411128 dan Kode Jenis Setoran (KJS) 422. ID Billing Tax Amnesty dapat dibuat secara online di aplikasi eBillling Online Pajak. Setelah itu wajib pajak dapat melakukan pembayaran pajak di Online Pajak yang telah bekerja sama dengan Bank Persepsi (Bank resmi yang menerima pembayaran pajak dan menyalurkan ke kas Negara).

PAS Final dapat dilaksanakan dengan menyampaikan Surat Pemberitahuan Masa PPh Final, dilampiri dengan Surat Setoran Pajak dengan Kode Akun Pajak 411128 dan Kode Jenis 422, ke KPP tempat wajib pajak terdaftar. Prosedur PAS Final ini hanya dapat dimanfaatkan selama Ditjen Pajak belum menerbitkan Surat Perintah Pemeriksaan (SP2) Pajak sehubungan dengan ditemukannya data harta yang belum diungkapkan.

Bagi wajib pajak yang melakukan usaha wajib melampirkan surat pernyataan mengenai besaran peredaran usaha yang dilampirkan dalam Surat Pernyataan apabila tidak terdapat pada SPT PPh terakhir. Surat pernyataan mengenai besaran penghasilan bruto pada tahun pajak terakhir merupakan surat pernyataan yang dibuat oleh wajib pajak yang digunakan sebagai dasar untuk menentukan penghasilan bruto pada tahun pajak terakhir. Penghasilan bruto yang diterima oleh wajib pajak adalah penghasilan yang sesungguhnya diterima oleh wajib pajak pada tahun pajak terakhir (PP No.36/2017 Pasal 4 Ayat 4).

Surat Perintah Pemeriksaan (SP2) adalah surat perintah untuk melakukan pemeriksaan dalam rangka menguji kepatuhan pemenuhan kewajiban perpajakan dan/atau untuk tujuan lain dalam rangka melaksanakan ketentuan peraturan perundang-undangan perpajakan. Pemeriksaan dilakukan oleh Pemeriksa Pajak yang tergabung dalam suatu tim Pemeriksa Pajak berdasarkan Surat Perintah Pemeriksaan (SP2). SP2 diterbitkan untuk satu atau beberapa Masa Pajak dalam suatu Bagian Tahun Pajak atau Tahun Pajak yang sama atau untuk satu Bagian Tahun Pajak.

Tuan A merupakan pengusaha catering pada tahun 2015 berupa penghasilan usaha katering sebesar dua miliar rupiah yang dikenai pajak penghasilan bersifat final dan penghasilan sebagai pembawa acara di televise sebesar lima ratus juta rupiah yang dikenai pajak penghasilan yang bersifat final. Berdasarkan peraturan maka penghasilan bruto Tuan $\mathrm{A}$ adalah dua miliar lima ratus juta rupiah dan dikenakan tarif $12,5 \%$

Tuan B merupakan karyawan yang menerima gaji dari peusahaan tempat bekerja. Tuan B tidak melakukan usaha dan atau pekerjaan bebas. Pada tahun 2015 Tuan B menerima penghasilan berupa gaji sebesar Rp 120.000 .000 yang dikenai pajak penghasilan yang tidak bersifat final,bunga deposito sebesar Rp 5.000.000 yang dikenai pajak bersifat final, dan sewa tanah dan bangunan sebesar 
Rp 50.000.000 yang dikenai pajak penghasilan bersifat final. Berdasarkan peraturan maka penghasilan bruto Tuan B adalah Rp 175.000.000 yang dikenakan tariff 12,5\%.

Tuan C telah memperoleh surat keterangan namun DJP menemukan harta berupa mobil yang belum dilaporkan dalam SPT PPh dan tidak diungkapkan dalam Surat Pernyataan. Tuan C tidak menyampaikan SPT PPh Terakir dan Surat Pernyataan menganai besaran peredaran usaha. Pada saat pemeriksaan penghasilan bruto pada Tahun Pajak Terakhir Tuan $\mathrm{C}$ adalah penghasilan usaha bengkel dua ratus juta rupiah dan tidak dikenakan $\mathrm{PPh}$ Final dan penghasilan deposito sebesar lima juta rupiah yang dikenai PPh Final. Dirjen Pajak memiliki data lain mengenai penghasilan Tuan $\mathrm{C}$ yaitu penghasilan usaha bengkel satu miliar rupiah yang dikenai pajak penghasilan bersifat final dan deposito enam ratus lima puluh juta rupiah yang dikenai pajak penghasilan bersifat final. Mengingat Tuan C berdasarkan data dan atau informasi lain yang dimiliki Dirjen Pajak menerima penghasilan bruto yang bersumberselain dari pekerjaan bebas sebesar enam ratus lima puluh juta rupiah dan memiliki pekerjaan bebas pada Tahun 2015 sebesar satu miliar enam ratus lima puluh juta rupiah maka tarif yang dikenakan adalah $30 \%$.

Tuan D merupakan karyawan yang menerima gaji dari perusahaan. Selain itu Tuan D adalah pengusaha jasa pencucian motor. Pada tahun Pajak 2015, Tuan D menerima penghasilan berupa: gaji sebesar Rp 120.000.000 yang dikenai pajak penghasilan yang tidak bersifat final, penghasilan usaha pencucian motor sebesar $\mathrm{Rp}$ 1.500.000.000 yang dikenai pajak penghasilan yang bersifat final, bunga deposito sebesar Rp 5.000.000 yang dikenai pajak penghasilan yang bersifat final, dan sewa tanah dan bangunan sebesar Rp 50.000.000 yang dikenai pajak penghasilan yang bersifat final. Berdasarkan ketentuan Peraturan Pemerintah maka penghasilan bruto tuan D yang bersumber selain dari usaha dan/atau pekerjaan bebas sebesar Rp 175.000.000 dan memiliki jumlah penghasilan bruto dari usaha dan/atau pekerjaan bebas dan selain dari usaha dan/atau pekerjaan bebas pada Tahun Pajak 2015 sebesar Rp 1.675.000.000. Maka tarif yang berlaku bagi Tuan D sebesar $12,5 \%$.

Bagi wajib pajak yang mengikuti pengampunan pajak namun belum atau kurang mengungkapkan Harta Bersih dalam Surat Pernyataan. Tuan D mengikuti pengampunan pajak dan memiliki harta bersih tambahan berada di dalam NKRI sebesar Rp 1.000.000.000 dan berada di luar wilayah NKRI dan akan dialihkan dan diinvestasikan ke dalam wilayah NKRI sebesar Rp 400.000.000. informasi pelaksanaan pengampunan pajak adalah 10 Maret 2017 menyampaikan surat pernyataan ke KPP; 20 Maret 2017 diterbitkan surat keterangan; 9 Agustus 2019 Direktur Jenderal Pajak menemukan data dan/atau informasi mengenai harta berupa tanah dan bangunan yang diperoleh tahun 2010 yang belum diungkapkan dalam surat pernyataan. Berdasarkan nilai dari hasil penilaian Direktur Jenderal Pajak, besarnya pajak penghasilan nilai harta berupa tanah dan bangunan pada tanggal 31 Desember 2015 sebesar Rp 20.000.000.000 dan sisa pokok utang terkait harta pada tanggal 31 Desember 2015 adalah Rp 12.000.000.000 maka dasar pengenaan pajak penghasilan adalah sebesar Rp 8.000.000.000

Bagian ini bertujuan untuk (a) menjawab masalah penelitian, (b) menganalisis dan menafsirkan temuan dan hasil penelitian, (c) mengkompilasi temuan penelitian ke dalam kumpulan pengetahuan sebelumnya, (e) menjelaskan implikasi lain dari hasil penelitian, termasuk keterbatasan penelitian dan kemungkinan dilakukan penelitian lanjutan sebagai konfirmasi atau yang bersifat memperdalam.

\section{KESIMPULAN}

PAS Final merupakan suatu singkatan dari Pengungkapan Aset Sukarela Dengan Tarif Final. Dalam PAS Final harta yang tidak diikutkan dalam program pengampunan pajak akan dikenakan pajak sesuai dengan ketentuan PMK No.165/PMK.03/2017 dan dikenakan tarif final yang diatur pada Peraturan Pemerintah PP No.36/2017. Program PAS Final bertujuan agar wajib pajak yang memiliki harta yang belum dilaporkan dalam SPT PPh sampai dengan tahun 2015 dan tidak diikutkan dalam program pengampunan pajak tidak dikenakan denda Pasal 18 Undang-Undang No. 11 Tahun 2016 tentang Pengampunan Pajak sebesar 200\%. Jika diterapkan pasal 18 undang-undang pengampunan pajak maka harta yang belum dilaporkan dalam SPT PPh Tahunan sampai tahun 2015 dan sampai dengan tahun 2017 tidak diikutkan program pengampunan pajak maka dianggap sebagai penghasilan yang harus dibayar pokok pajaknya dan denda 200\% (Pasal 18 UU No. 11 Tahun 2016).

Tarif pajak yang dikenakan pada harta yang belum diungkapkan pada periode PAS Final ditetapkan dalam pasal 3 ayat 2 PP No. 36 Tahun 2017 yaitu untuk wajib pajak badan dikenakan tarif $25 \%$, wajib pajak orang pribadi $30 \%$ dan wajib pajak tertentu $12,5 \%$ yang dimaksud dengan wajib pajak tertentu adalah wajib oajak yang menerima penghasilan bruto dari usaha dan/atau pekerjaan bebas pada Tahun Pajak Terakhri paling banyak empat miliar delapan ratus juta rupiah; wajib pajak yang menerima penghasilan bruto selain dari usaha dan/atau pekerjaan bebas pada Tahun Pajak Terakhir paling banyak enam ratus tiga puluh dua juta rupiah atau wajib pajak yang menerima penghasilan bruto dari usaha dan/atau pekerjaan bebas paling banyak empat miliar delapan ratus juta rupiah.

Ditjen Pajak telah diberikan kewenangan untuk mengakses data keuangan yang dimiliki oleh lembaga keuangan seperti perbankan dan pasar modal sesuai UU Nomor 9 Tahun 2017. Selain itu, data yang dimiliki Ditjen Pajak anatara lain izin usaha, izin penangkapan ikan, izin pertambangan, perkebunan, dan kehutan, izin mendirikan bangunan, registrasi produk obat dan makanan, dan kepemilikan tanah, kendaraan bermotor, hotel dan restoran. Sehingga mulai tahun 2018 , lembaga keuangan secara rutin memberikan data keuangan kepada Ditjen Pajak. Termasuk data keuangan dari 100 negara lain yang telah sepakat bertukar informasi keuangan dalam rangka memerangi pelarian pajak lintas Negara. Oleh karena itu, bagi wajib pajak baik yang belum dan terlebih khusus bagi wajib pajak yang telah mengikuti Amnesti Pajak dan masih belum melaporkan hartanya untuk segera memanfaatkan kesempatan PAS Final sebagaimana diatur dalam PMK-165, sebelum Ditjen Pajak menemukan data harta yang belum dilaporkan tersebut dan akan dikenai sanksi. 


\section{REFERENSI}

[1] Undang-Undang No. 11 Tahun 2016 tentang Pengampunan Pajak

[2] Peraturan Menteri Keuangan No.165/KMK.03/2017 tentang PAS Final

[3] Peraturan Pemerintah No.36/2017 tentang

[4] Pengenaan PPh atas Penghasilan Tertentu Berupa Harta Bersih yang Diperlakukan atau dianggap sebagai Penghasilan

[5] Undang - Undang Perpajakan Tahun 2008 Nomor 36 Tentang Pajak Penghasilan.

[6] Undang - Undang Perpajakan Tahun 2007 Nomor 28 Tentang Ketentuan Umum dan Tata Cara Perpajakan

[7] Yin, Robert K, 2006 Studi Kasus Desain dan Metode, terjemahan Mudzakir Djauzi, Raja Grafindo Persada, Jakarta. 